KAPL-P-000047

(K96048)

CONF- $9605348--$

\title{
RECENT PROGRESS IN INGAASSB/GASB TPV DEVICES
}

\author{
Z.A. Shellenbarger, M.G. Mauk, L.C. DiNetta, G.W. Charache
}

May1996

\section{NOTICE}

This report was prepared as an account of work sponsored by the United States Government. Neither the United States, nor the United States Department of Energy, nor any of their employees, nor any of their contractors, subcontractors, or their employees, makes any warranty, express or implied, or assumes any legal liability or responsibility for the accuracy, completeness or usefulness of any information, apparatus, product or process disclosed, or represents that its use would not infringe privately owned rights.

Operated for the U. S. Department of Energy by KAPL, Inc. a Lockheed Martin company

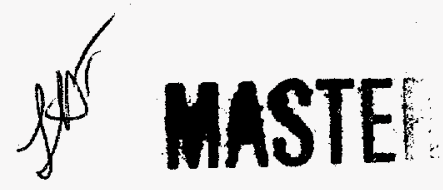




\section{DISCLAIMER}

This report was prepared as an account of work sponsored by an agency of the United States Government. Neither the United States Government nor any agency thereof, nor any of their employees, makes any warranty, express or implied, or assumes any legal liability or responsibility for the accuracy, completeness, or usefulness of any information, apparatus, product, or process disclosed, or represents that its use would not infringe privately owned rights. Reference berein to any specific commercial product, process, or service by trade name, trademark, manufacturer, or otherwise does not necessarily constitute or imply its endorsement, recommendation, or favoring by the United States Government or any agency thereor. The views and opinions of authors expressed herein do not necessarily state or reflect those of the United States Government or any agency thereof. 


\section{DISCLAIMER}

Portions of this document may be illegible in electronic image products. Images are produced from the best available original document. 


\title{
IEEE PVSC May $13-17,1996$
}

\section{Recent Progress in InGaAsSb/GaSb TPV Devices}

\author{
Z.A. Shellenbarger, M.G. Mauk, and L.C. DiNetTA \\ AstroPower, Inc. Solar Park, Newark, DE 19716-2000 \\ G.W. Charache \\ Lockheed Martin Corp. P.O. Box 1072, Schenectady, NY $12301-1072$
}

\section{SUMMARY}

AstroPower is developing inGaAsSb themophatovoltaic (TPV devices. This photovoltaic cell is a two-layer epltaxlal InGaAsSb structure formed by liquid-phase epitaxy on a GaSb substrate. The (direct) bandgap of the $1 n_{1 . x} \mathrm{Ga}_{x} \mathrm{As}_{1 . y} \mathrm{Sb}_{y}$ alloy is 0.50 to $0.55 \mathrm{eV}$. depending on its exact alloy composition $(x, y)$; and is closely lattice-matched to the GaSb substrate. The use of the quatemary alloy, as opposed to a ternary alloy - such as, for example. InGaAs/nP - permits low bandgap dovices optimized for 1000 to $1500^{\circ} \mathrm{C}$ thermal sources with, at the same time. near exact lattice matching to the GaSb substrate. Lattice matching is important since even a small degree of lattice mismatch degrades devlce performance and rellabiiity and increases processing complexity.

Internal quantum efficiencies as high as $95 \%$ have been measureo at a wavelength of 2 microns. At 1 micron wavelengths. intemal quantum efficiencies of $55 \%$ have been observed. The open-circuit voltage at currents $0: 0.3 \mathrm{Acm}^{2}$ is 0.220 volts and $0.260 \mathrm{~V}$ for current densities of $2 \mathrm{Acm}$. Fill factors of $56 \%$ have been measured at $60 \mathrm{~mA} / \mathrm{cm}^{2}$. However. as current density increases there is some decrease in fill factor. Our results to date show that the GaSb-based quatemary compounds provide a viable and high performance energy conversion solution for thermophotovoltalc systems operating with 1000 to $1500^{\circ} \mathrm{C}$ source lemperaturee.

\section{INTRODUCTION}

We report our latest results on in GaAsSb themophotovoltaic (TPV cells. TPVs are p-n junction semiconductor devices that convert photons emitted by a heated source directly into electrical power. For TPV systems ublizing thermal radiation from an amittar heated at 1000 to $1500^{\circ} \mathrm{C}$, there is a need for low-bandgap cells with a high spectral response in the range of 1500 to $2500 \mathrm{~nm}$ wavelength. This implles a TPV cell with a bandgap of $-0.5 \mathrm{eV}$. One important potential application is the radioisotope General Purpose Heat Source (GPHS) where $1100^{\circ} \mathrm{C}$ blackbody radiation Ean be used for thermophotovoltaic energy conversion. In this paper we describe high-fficiency TPV devices based on lattice matched $\ln _{0.00} G_{0.92} A s_{0.07} S b_{0.9 s}\left(E_{G}=0.53 \mathrm{eV}\right.$ ) epitaxial layers on GaSb substrates. To our knowledge, this is the irst report of the InGaAsSb quatemary alloy applied to TPV devices.

Several theoretical studies have indicated that photovoltaic colls based on the inGaAsSb quaternary alley are gcod candicates for TPV applications that require high spectral response in the 1500 to $2500 \mathrm{~nm}$ wavelength range. Depending on its alloy composition $(x, y)$, the direct bandgap of the $\ln _{1 . x} \mathrm{Ga}_{x} \mathrm{As}_{4 . y} \mathrm{Sb}_{\mathrm{y}}$ alloy varies from $018 \mathrm{eV}$ (inSb) to $143 \mathrm{eV}$ (GaAs). The quaternary alloy can be closely lattice-matched to the GaSb substrate provided the composition is restrained lo values such that $y=0.1+09 x$. With this lattice matening condition. the 
bandgap of the quatemary alloy ranges from approximately 0.3 to $0.7 \mathrm{eV}$. However, there is a further limitation due to a wide solid-phase misciblity gap in this quatemary at typical growth temperatures. The miscibility gap evidently precludes bandgaps in the range of 0.35 to $0.5 \mathrm{\theta V}$. Therefore, for the spectral range of interest, we assume the lowest attainable bandgap is 0.50 to $0.52 \mathrm{eV}$. This bandgap range corresponds to an optical absorption edge of 2380 to 2480 nanometers.

It is worth emphasizing that the use of the quatemary alloy, as opposed to a temary alloy- 6uch as. for example. InGaAs provides the needed bandgap with. at the same time, near-exact lattice matching to the GaSb substrate. Lattlce-matching is important since even a small degree of lattice mismatch degrades device performance and reliability. Although there are epitaxy techniques to partially ameliorate effects associated with lattice mismatch of temary alioy layers on binary substrates (6.g. defect-filtering superlattices. internoted grciwth. regimens, etc.). We believe the use of the quatemary alloy to avoid lattice mismatch altogether is a simpler ar.o more effective approach.

The TPV device we are making is a two-layer epitaxial inGaAsSb structure formed by liquid-phase epitaxy on a GaSb substrate at a growth temperature of $515^{\circ} \mathrm{C}$. Liquid-Phase Epitaxy (LPE) is a well-estabilshed technology for III-V compound semiconductor devices. A major advantage of LPE for this application is the high material quality, and more specifically, the long minority cartier diffusion lengths, that can be achleved. This results in devices which are equal or superior in pertormance to those made by other epitaxy processes such as molecular beam epitaxy (MBE) or metal organic chemical vapor depositton (MOCVD). Another major advantage is that LPE is a simple. inexpensive, and safe method for semiconductor device tabrication. Significantly, the LPE process does not require or produce any highiy toxic or dangerous substances - in contrast to MOCVD. Also, the epitaxial growth rate with InGaAsSb LPE is $\sim 2$ microns/minute which is ten to hundred times faster than MOCVD or MBE. Wo have successtulty scaled up the LPE process for epitaxial growth in a semi-continuous mode on 3-inch diameter wafers. This, combined with the high growth rates. will dramatically improve the manufacturing throughput compared to traditional and more costly epitaxy processes. Our objective is to develop an efitaxial growth technology to produce low-cost. large-area. high efficiency TPV devices.

\section{EPITAXIAL GROWTH ANO FABRICATION OF InGaA\&SB TPV CELLS}

InGaAsSb photodlodes, light-emitting diodes, and double heterostructure injection lasers made by llquidphase epitaxy have been previously reported. We have adapted this technology for the production of inGaAsSb TPV cells.

We use a standard horizontal stidebaat technique for the liquid-phase epitaxial growth of the InGaAsSo. The graphite slideboat is situated in a sealed quartz tube placed in a microprocessor-controlled. programmable. three-zone tube fumace. The growth ambient is palladium-diffused hydrogen at atmospheric pressure with a flow rate of $300 \mathrm{~m} / \mathrm{min}$.

The substrates are 500-micron thick, chemically polished (100) oriented, n-type GaSb wafers obtained from MCP Water Technology, Ltd. (Milton Keynes. UK) or Firebird Semiconductor, Ltd. (Trail, BC. Canada). Substrates are doped to $3-5 \times 10^{17} \mathrm{~cm}^{-3}$ with tellurium. The substrate resistivity is $9 \times 10^{-3} \Omega \mathrm{cm}$. and the average etch-pit density is approximately $1000 \mathrm{~cm}^{-2}$.

The growth solutions are indium $\left(x_{1 n}=0.59\right)$. gallium $\left(x_{a_{4}}=0.19\right)$. antimony $\left(x_{9 b}=0.21\right)$. and arsenic $\left(x_{A_{2}}=0.01\right)$. The melts are formulated with $3-$ to $5-\mathrm{mm}$ shot of high purity $(99.9999 \%)$ indium. gallium. and antimony metals and arsenic added as undoped InAs polycrystalline material. The total weight of the melt is about $10 \mathrm{~g}$ Pror to growth. the melts are baked out at $700^{\circ} \mathrm{C}$ lor fifteen hours under flowing hydrogen to de-oxidize the metallic melt components and outgas residuat impurities. After bake-out. appropnate dopant impurities are added to each melt The first melt for the growth of the n-tyce inGaAsSo base tayer contains tin or tellunum. The small amount of Te needed to dope the laver (atomic fraction in the melt $\equiv 10^{\circ}$ ) is problematic. For raproductble doping. a weighable amount of Te is adced as 100 to $2 \mathrm{CO} \mathrm{mg}$ of Te-doped $\mathrm{GaSb}\left(\mathrm{C}_{\mathrm{T}}=10^{19} \mathrm{~cm}^{.3}\right)$ Tin is adced to 
the meil as $1010200 \mathrm{mg}$ of high purity shot. Our preliminary rasults (Section 3) suggest that high n-type doping concentrations can be achieved more readily with tin than with telturium. However, the relatively high liquid-phase concentration of tin atter3 the molt composition nesded to grow the lartice-matched in GaAsSb quatemary with the cesired bandgap. For higher tin doping levels, we will need to re-optimize the melt compositions to include the effects of dilution with additional th. This will require a phase equilloria analysis and model of a 5 -component system (In-Ga-Ag-Sb-Sn). The second melt for the growth of the p-type emitter contains 5 to $100 \mathrm{mg}$ gemanium. Presently, we are beginning a more detalled and systematic characterization of impurty segregation and doping in the in-Ga-As-Sb quatemany system with the aim of achieving better control and a greater range of doping concentrations.

The melts are equiliorated for 1 hour at $530^{\circ} \mathrm{C}$ and then cooled at a rate of $0.7^{\circ} \mathrm{C} / \mathrm{min}$. At $515^{\circ} \mathrm{C}$. the substrate is contacted with the first melt for two minutes to grow a 5-micron thick n-type InGaAsSo base laye: Next. the substrate is moved to the second melt for 5 seconds to grow a 0.3 -micron thick p-type InGaAsSb e.Titter layer.

Front and back onmic contacts are tormed on the epitaxial InGaAsSb/GaSb structure by standard processing techniques. The back of the substrate is metallized by plating with a $200 \cdot \mathrm{nm}$ thick electron-beam evaporated Au:Ge:Au:Ni layer and alloyed at $300^{\circ} \mathrm{C}$. The front contact is a grid of 10-micron wide metallization lines with 100-micron spacing and a single $1 . \mathrm{mm}$ wide center busbar. The grid is formed by a photolithography linoff process with a $200-\mathrm{nm}$ thick electron-beam evaporated Au:Zn:Au metallization. The front grid is thickened to 5 microns by gold electroplating. The front contact is not sintered. The substrate is masked and pattemed to define a $1 \mathrm{~cm} \times 1 \mathrm{~cm}$ device and isolation etched with a potassium iodlde - iodine "gold" etch. Most of cur TPV cells are $1 \mathrm{~cm} \times 1 \mathrm{~cm}$ in area: athough larger cells $(2 \mathrm{~cm} \times 2 \mathrm{~cm})$ with comparable performance have also been made. In order to simplity the spectral response analysis, we elected not to apply any anti-reflection coatings :0 the cells. FIGURE 1 is a top-view photograph of a $1 \mathrm{~cm} \times 1 \mathrm{~cm}$ InGaAsSD TPV cell.

\section{TFY DESIGN AND OPTIMIZATION}

FIGURE 2 shows the TPV device design in cross-section. The fabricated cells have a 0.3 to 0.5 micron thick p-ype ernifter with a Ge concentration of approximately $10^{19} \mathrm{~cm}^{-3}$. as indicated by Secondary lon Mass Spectroscopy (SIMS). A thicker, more heavily doped p-layer will reduce the sheet resistance of the emitter and therefore improve the fill-factor, but will tend to reduce spectral response due to higher free-carrier absorption and increased sensitivity to front surface minority carrier secombination.

The base thickness in our cells ranges from 3 to 5 microns with a Te or Sn concentration of about $10^{15}$ to $10^{18} \mathrm{~cm}^{3}$. as determined from capacitance-voltage measurements and SIMS. FIGURE 3 shows the SIMS depth profile indicating the abruptress of the p-n junction and the depth uniformity of the doping concentrations. There is apparently very little smearing of the doping profile due to diffusion or segregation of dopants. Discrepancies between the Te dopant concentration measured by SIMS (total impurity concentration) and that implied by capacitance-voltage measurements (net donor concentration) indicate that much of the To is either not lonized or else is compensated. This is a common problem in Te doping of III-V semiconductors. especially in GaSb-based materlals. and is probably due to the formation of electrically inactive tellunde complexes or compounds in the material. Increasing the Te concentration in the melt showed a "saturation effect" in that the Te doping level did not increase in proportion to the Te concentration in the liquid phase. Our most recent devices incorporate tin as the $n$-type base dopant and have base dopings targeted around $10^{17} \mathrm{~cm}^{-3}$. Modeling indicates that base dopings in this range will yield the optimum open-circuit voltages and short-wavelength quantum efficiencies. 


\section{TPV DEVICE EYALUATION}

We present external and intemal spectral response and current-voltage characteristics for $1 \mathrm{~cm} \times 1 \mathrm{~cm}$

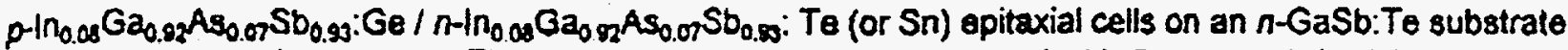
produced as described above. The extemal spectral response of a typical lnGaAsSO TPV cell is shown in FIGURE 4. FIGURE 5 shows the corresponding internal spectral response. The lower extemal spectral response is due to grid shading and reflection of incident light from the uncoated InGaAsSb emitter surface. The grid shading is $18.2 \%$. The absorption edge implied by the spectral response measurements of a number of samples ranged from approximately 2200 to $2250 \mathrm{~nm}$. At a wavelength of $2000 \mathrm{~nm}$, intemal quantum efficiencies as high as $95 \%$ have been measured, and at a wavelength of 1 micron, Intemal quantum efficiencies of almost $55 \%$ have been observed. The intemal quantum efficlency averaged over the spectral region from 1 to 2 microns wavelength is $60 \%$. (It should be noted that for the intended TPV applications, the response of the cell tor wavelengths less than 1.5 microns is not important)

The $1 \mathrm{~cm} \times 1 \mathrm{~cm}$ InGaAsSb TPV cells were tested under simulated infrared light using a ZnSe-fltered tungsten source (Carley Lamps. Inc.. Torrance, CA) with a spectral emission in the 800 to $3000 \mathrm{~nm}$ wavelength range. Under an illumination intensity corresponding to a short-circult current density of $2 \mathrm{Avcm}^{2}$, open-circuit voltages as high as 0.280 volts have been measured. FIGURE 6 shows the current-voltage characteristles of a $1 \mathrm{~cm} \times 1 \mathrm{~cm}$ InGaAsSb TPV cell under an infrared illumination intensity that yields a short-circuit current density of $62.4 \mathrm{mAv \textrm {cm } ^ { 2 }}$ and a open-cicuit voltage of $0.178 \mathrm{~V}$. The fill-factor is 0.57 . To date. the best filt-factors observed are less than 0.6. We believe that one cause of the somewhat low flli-tactors is series resistance, which is discussed further in the next section. FIGURE 7 shows open-circuit voltage vs. short-circuit current for varying light intensity. The open-circuit voltage increases logarithmically with illumination intensity and an open-circuit voltage of $-0.250 \mathrm{~V}$ is reached for current densities of $1 \mathrm{Acm}^{2}$. The diode idealty factor in the voltage range of 0.1 to $0.25 \mathrm{~V}$ is close to 2 . Implying that high injection is dominant in this voltage range.

\section{CONCLUSION AND DISCUSSION}

Our results to date have demonstrated the potential of InGaAsSb TPV devices made by liquid-phase epitaxy. We believe there is still room for substantial efficiency enhancements in these devices by optimization of the doping levels and layer thicknesses. Further improvements might include wido bandgap lattico-matched AlGaAsSb window layers for front surface passivation, and AIGaAsSb back-surfaco feld cladding layers to reduce the reverse saturation current and thereby increase the open-circuit voltage. Highly doped contact layers will provide lower series resistance, as will substrate thinning. Lower serles resistance will lead to higher fill factors. Thinning the substrate will also improve heat sinking of the device.

The required performance of a TPV device is dependent on its system application. Spectral control of thermal emitters. the use of selective filters and reflectors, heat transfer, and photon recycling effects need to be included in the device design and system optimization. These considerations are not usually relevant for conventional photovoltaic devices and therefore the design and optimization nules for TPVs will be significantly different than those for solar cells. For example. grid obscuration and reflection are not necessarily losses in TPV systems if photons reflected from the front sufface are re-absorbed by the emitter. Our next generation of InGaAsSb TPV devices will incorporate design features to fully exploit photon recycling effects

\section{REFERENCES}

A. andaspaeva, a.N. Baranov. A. Guseinov. A.N. Imenkov. L.M. litvak. G.M. Fllaretova, and y $P$ yakovev. - Highly Efficient GalnAsSb Light-Emitting Diodes $(\lambda=2.2 \mathrm{~m} . \eta=4 \% . T=300 \mathrm{~K})$ " Soviet Technical Physics Letiers 14,5 (1988) $377-378$. 


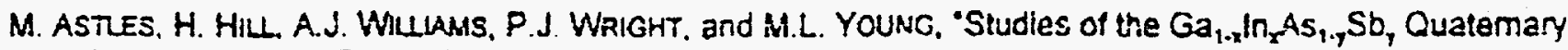
Alloy System I. Liquid-Phase Epitaxial Growth and Assessment J. Electronic Materials 15, 1 (1986) $41-49$.

A.N. Baranov, A.M. Lituak. KD. Moiseev, N.A. CHarykov, and V.V. Shertshev. Melt-Solid Phase Equilibria in the In-Ga-As-Sb and In-As-P-So Systems" Russian J. Physical Chemistry 64, 6 (1990) 884-886.

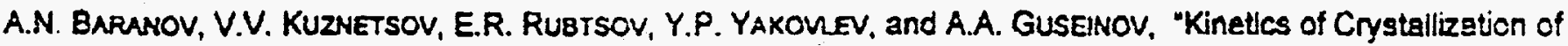
the Gay $\ln _{1 . x} A s_{y} S_{1-y}$ Solld Solutions from the Liquid" Russian J. Physical Chemistry 85, 12 (1991) 1713-1716.

C. Caneau, A.K. SRivastava, A.G. Dental. J.L. Zyskino, ano M.A. Poulack, "Room-Temparature GalnAsSb/AIGaAsSb DH Injection Lasers at $2.2 \mu \mathrm{m}^{*}$ Electronics Leters 21, 18 (1985) 815-817.

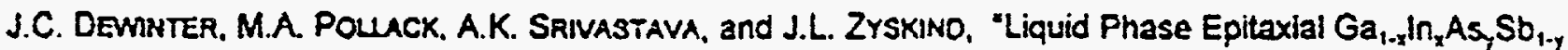
Lattice-Matched to (100) GaSb over the 1.17 to $2.33 \mu \mathrm{m}$ Wavelength Range" J. Electronic Materials 14, 6 (1985) 729-747.

A.E. Draxin, P.G. Eliseev, B.N Sverdlov, A.E. Bochkarev, L.M. Dolginov, and L.V. Druzhinina. "InGastas Injection Lasers" IEEE J. Quantum Electronics QE-23, 6 (1987) 1089-1094.

A. JOULLIE, F. JIA HUA, F. KAROUTA, and H. MANI, "LPE Growth of GainAsSb/GaSb System: The importance of the Sign of the Lattice Miematch" J. Crystal Growth 76 (1986) 309-318.

H. KANO. S. MiYazawA, and K. Sugryase, "Liquid-Phase Epitaxy of $G a_{1 y} l \Omega_{\gamma} A s_{x} S b_{1-x}$ Quatemary Alloys on GaSb" Japenese J. Applied Physics 18, 11 (1979) 2183-2184.

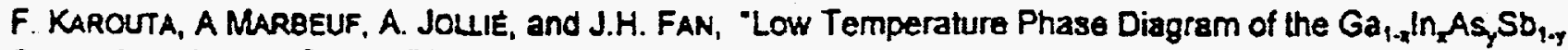
System" J. Crystal Growth 79 (1986) 445-450.

N. KobaYASHI, Y. HoRikoshI, and C. Uenura, Liquid-Phase Epitaxial Growth of InGaAsSb/GaSb and InGaAsSb/AIGaAsSb DH Wafers" Japaneso J. Applied Physics 18, 11 (1979) 2169-2170.

J.8. MCNEElY, M.G. MAUK, and L.C. DiNetTA. "An InGaAsSb/GaSb Photovoltalc Cell by Liquid-Phase Epitaxy for Themophotovoltaic (TPV) Application“ Proc. 1st NREL Cont. on Themophotovoltale Generation of Electricity. 1994 T.J. COUTts and J.P. BENNER, eds., (New York: Americen insttute Physics, 1995) 221-225.

K. NAKasma, K. Osamupa, K. Yasuda, and Y. Murakami. The Pseudoquatemary Phase Diagram of the Ga-In-As-Sb System* J. Crystal Growth 41 (1977) 87-92.

N. KOBAYAshI and Y. HORIKOSHI. "Pseudoquatemary Phase Diagram Calcutation of $\ln _{1-x} \mathrm{Ga}_{x} \mathrm{As} \mathrm{s}_{1,} \mathrm{Sb}_{\mathrm{Y}}$ Quatemary System" Japanese J. Applied Physics 21, 1 (1982) 201-202.

K. Nakusima, K Osamuru. K YASUDA, and Y. MuPuKami. "The Pseudoquatemary Phase Dlagram of the Ga-InAs-Sb System J. Cystal Growth 11 (1977) 87-92.

E. Tournie. F. Pitard, A. Joullue, and R. Fourcade. "High Temperature Llquld Phase Epitaxy of (100) Oriented GalnAsSo Near the Miscibility Gap Boundary" J. Crystal Growth 104 (1980) 683-694.

M.M. WANLASS. J.S. WARD, K.A. EMERY, and T.J. COUTTS, "Ga $\ln _{1-x}$ As Themophotovoltaic Converters" IEEE ist Word Conference on Photovoltalc Energy Conversion (New York. IEEE Press, 1994) 1685.1681.

S. Wojtczux, E. Gagnon. 1. Geoffroy, and T. PARocos. " $\ln _{2} \mathrm{Ga}_{1 . x}$ As Themophotovoltaic Cell Performance vs. Bandgap" Proc. 1st NREL Conf. on Themophotovoltaic Generation of Electricity, 1994 T.J. CouTtS and J.P. RENNER. eds. (New York: Amencan institute Physies, 1985) 177-187. 


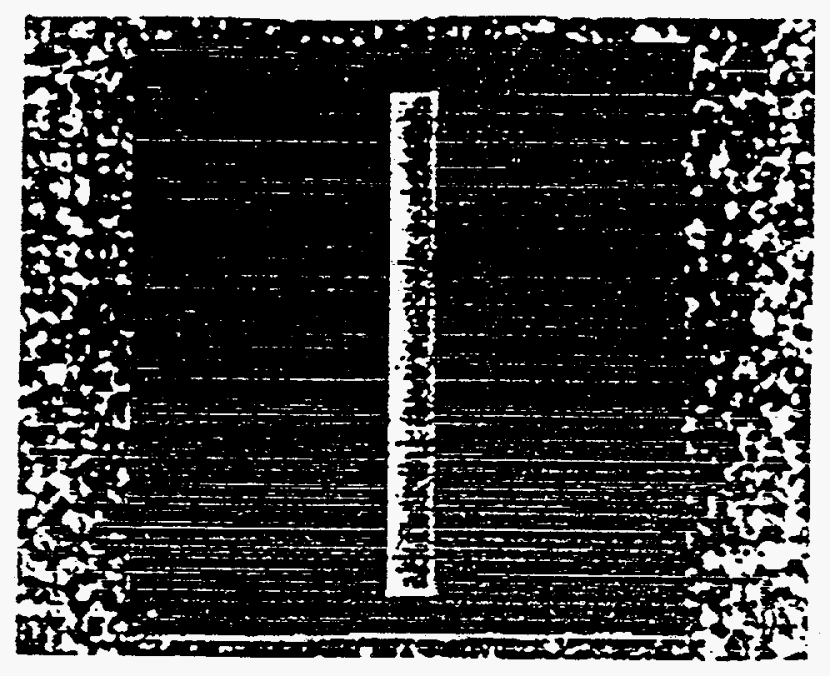

FIGURE 1: TOp-view Photograph of a $1 \mathrm{~cm} \times 1 \mathrm{~cm}$ InGaAsSb TPV Cell.

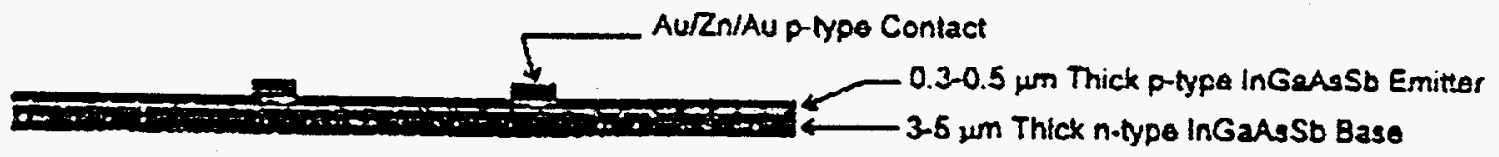

Gasb Substrate

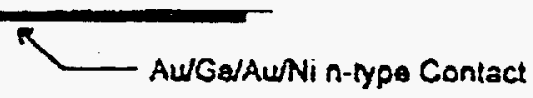

FIGURE 2: InGaAsSb/GaSb p-n Junction Thermophotovoltaic Cell Design.

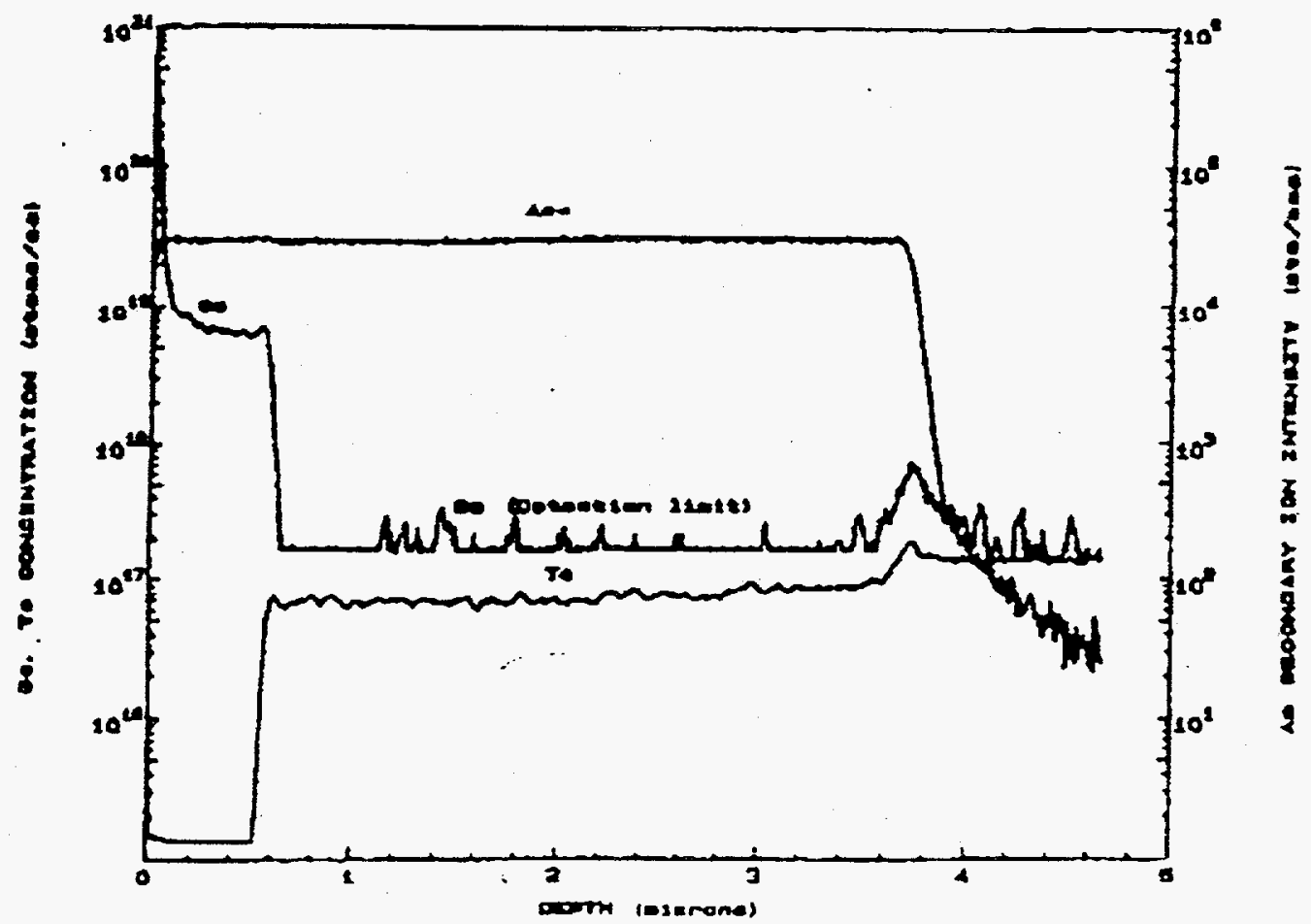

FIGURE 3: SIMS Depth Profile of Doping. 


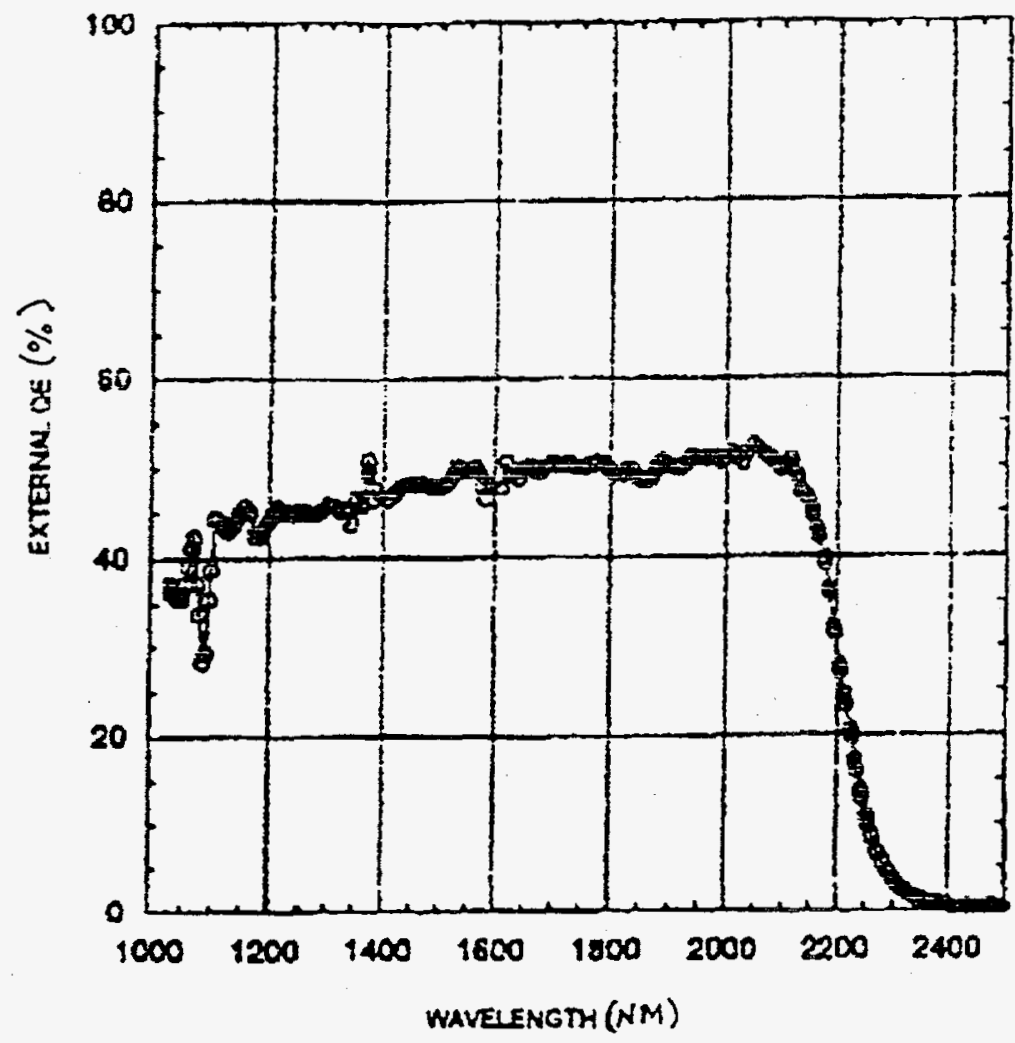

FIGURE 4: Extemal Spectral Response of InGaAsSb/GaSb p-n Junction Thermophotovoltaic Cell.

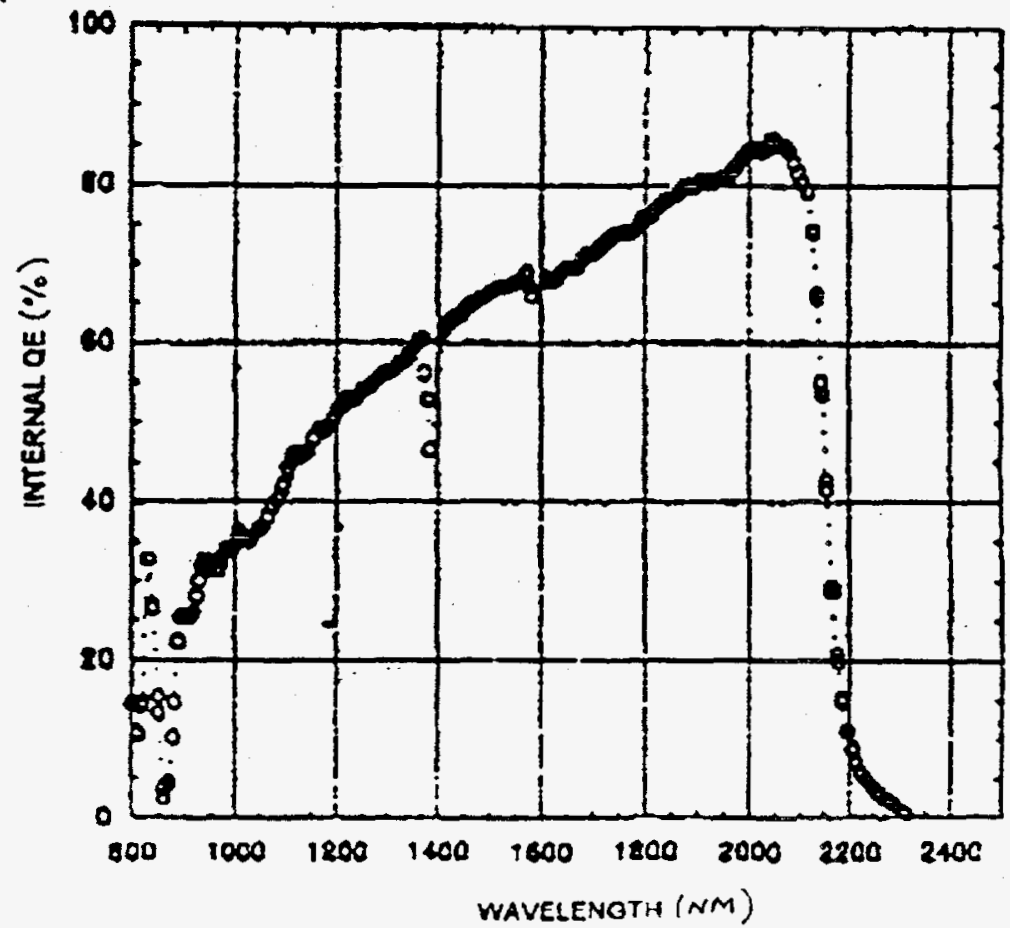

FIGURE 5: Intemal Spectral Response of InGaAsSo/GaSb p-n Junction Thermophotovoltaic Ceil 


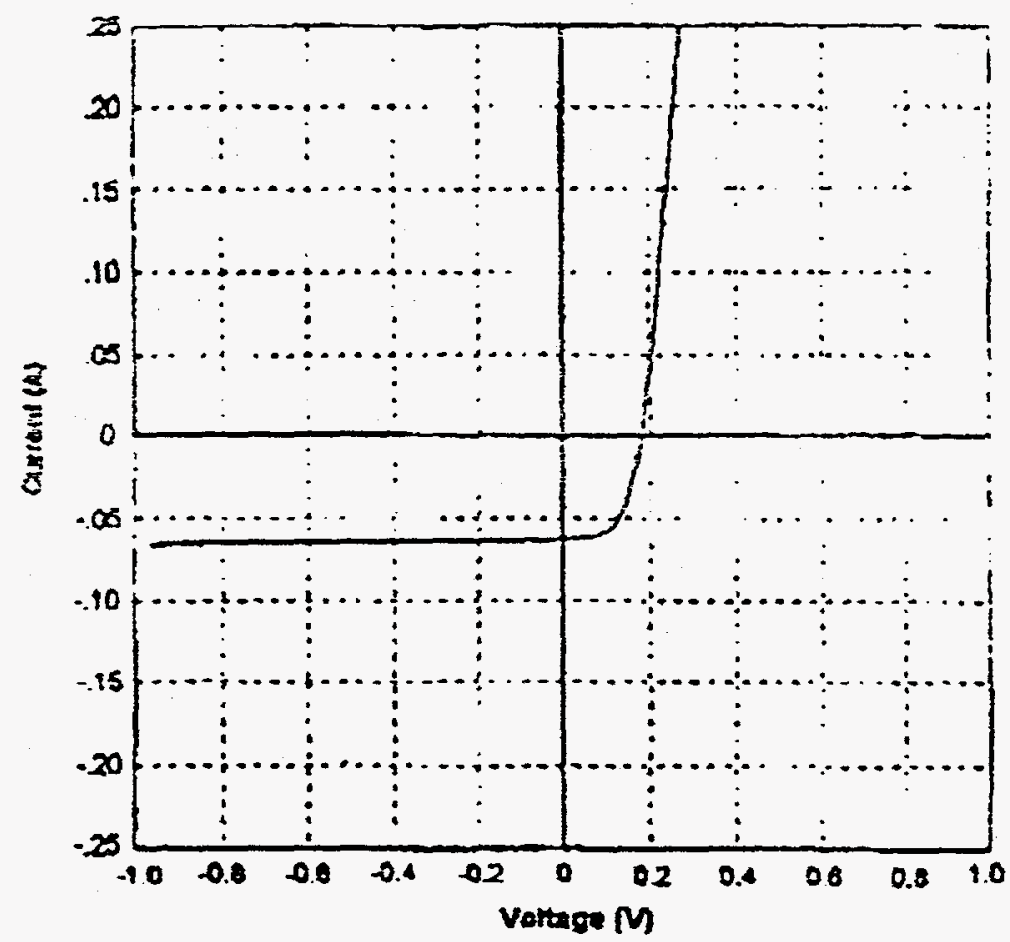

FIGURE 6: Current-Voltage Characteristc of $1 \mathrm{~cm} \times 1 \mathrm{~cm}$ InGaAsSb TPV Cell.

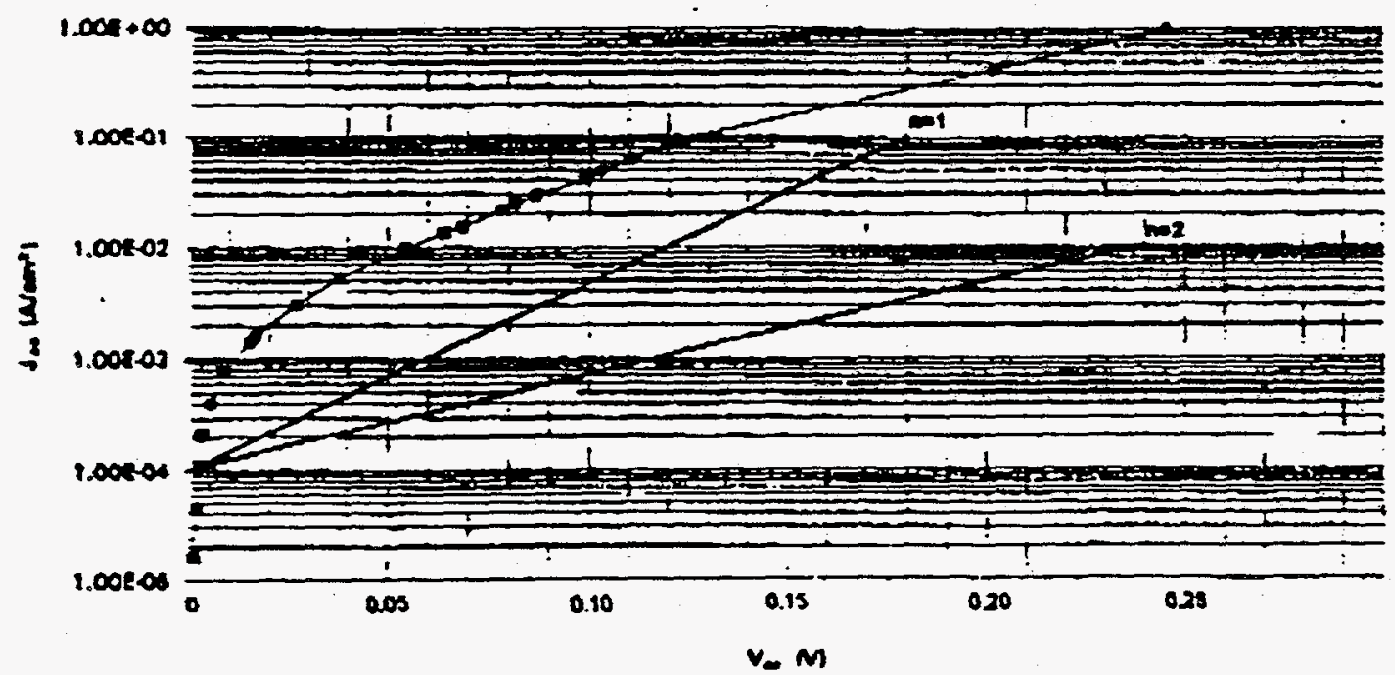

FIOURE 7: Open-Circuit Voltage vs. Short-Clrcuit Current for InGaAsSb TPV Cell under Varying Illumination intensity. 